\title{
The Nexus of Asset Composition with Accounting and Market Performance of Firms in Nigeria
}

\author{
Asian A Umobong ${ }^{1 *} \quad$ Uche T Agburuga $^{2}$ \\ 1.Department of Accounting, University of Port Harcourt, Choba, PMB 5326, \\ Port Harcourt, Rivers State, Nigeria \\ 2.Accounting and Bursary Departments, Federal University Otuoke, PMB 126, \\ Yenagoa, Bayelsa State, Nigeria
}

\begin{abstract}
This ex-post facto design study examined the link between asset composition and accounting and market performance of insurance, banking and manufacturing firms quoted on Nigeria Stock Exchange using cross sectional secondary data from 2013 to 2017. The asset structure decomposed into plant property and equipment, long term investment, intangible asset and current assets were regressed against accounting measures of return on asset and return on equity on the one hand and market measures of price earnings ratio, earnings yield, Tobin's $Q$ and market valuation on the other hand. Property plant and equipment, long term investments, intangible asset and current assets all returned a positive and statistically significant relationship with return on assets. Similar result were equally returned by the assets components in relation to return on equity except property, plant and equipment and long-term investment that posted negative and statistically significant result. The result further indicate a positive but not statistically significant relationship of current assets with price earnings ratio contrary to the negative but statistically significant relationship of property, plant and equipment with the same performance measure. Also, long term investment and intangible assets both have a positive and statistically significant relationship with price earnings ratio. The result also indicate that long term investment and current assets have a positive and statistically significant relationship with earnings yield. Conversely, property plant and equipment and intangible asset posted a negative and statistically significant relationship with earnings yield. Intangibles and current asset have a positive and statistically significant relationship with market valuation while on the other hand increases in property, plant and equipment and long term investment reduces market valuation and Tobin's Q in view of their negative but statistically significant relationship. The macroeconomic control variables of inflation and GDP and the microeconomic control variables of leverage and liquidity effectively performed their moderating roles between the dependent and the independent variables by differentially returning both positive and negative relationships. We recommend that IPO firms should invest less in PPE and Long-Term Assets to avoid negative investors pricing while at the same time increasing investment in current assets and developing intangibles. Also, firms with high asset base should increase leverage to enjoy tax advantage. We also recommend that firms with low asset base should avoid increased borrowing to mitigate risk of bankruptcy
\end{abstract}

Keywords: Earnings Yield, Price Earnings Ratio, Tobin's Q, Return on Assets, Return on Equity, Gross Domestic Product, Inflation, Leverage

DOI: $10.7176 / \mathrm{JESD} / 10-22-01$

Publication date: November $30^{\text {th }} 2019$

\section{Introduction}

The contribution of firms to the economic growth of Nigeria is tremendous. However, the recession that ensued recently and the consequential slowdown in economic growth adversely affected myriads of firms leading to declining performance. This ultimately result in retrenchment worsening unemployment, decline in demand for goods and services and low capacity utilization by firms. The high inflation rate, low purchasing power of the naira because of inflation dovetail into poor demand. The stock market is equally affected as the exchange is experiencing declining market capitalization and loss of investors' confidence. Many firms have been delisted from the stock exchange because of low trading activity and low performance. This is contrary to the expectations of various stakeholders who span across shareholders, employees, consumers, and government among others.

The contribution which the composition of assets make to the success of an entity has been a subject of debate over the decades. Modigliani \& Miller (1958) in their proposition of irrelevance of capital structure recognized asset as the determinant of firm value. Asset composition consist of fixed assets, current assets, intangibles and long-term investments. Firms use fixed assets to transform raw materials into finished goods. These assets are called property, plant, and equipment which include land, building, machinery, equipment, automobiles, furniture and fittings. Although fixed asset continues to gain prominence in firms, there is also the need to maintain sufficient current assets to enhance liquidity and satisfaction of short term obligations. This mix require a trade-off which probably affect profitability and investment. When the concentration of current asset is higher it is believed its contribution is also higher in relation to asset turnover and vice versa. The importance of asset to the firm is significant. Firstly, firms cannot commence or embark on expansion without assets because they require assets 
for production of goods or services. These assets measure the ability of the firms to survive and compete with other firms (Reyhani, 2012). The firms hold the assets because there is no effective rental market to sell or buy these assets. Some other firms hold assets (especially fixed assets) because of tax advantage derived for economic growth and technological development (Dong, Charles, \& Cai, 2012). Traditionally, the view is held that a positive relation subsists between firms engaging in production and non-current assets because producing firms required a high percentage of non-current assets to process raw materials into end-products. Growth in non-current assets are expected to raise future earnings because capacity utilization of these non-current assets is expected to increase production. Massive growth in non-current assets should propel profit because using these assets is expected to raise production (Kantudu, 2008). There is also the issue of firms timing asset sales as a strategy to massage earnings. Thus, firms can hold asset as security for loans, for production, for transaction purposes in which case they are targeting future sales for profit. There is also the argument that asset volatility increases firm value. Lewellen (1971) argued that for multi asset firms, the volatility level of assets affect valuation and concluded that decrease in asset correlation increases coinsurance effect and increase firm value. Greenbaum \&Thakor (1987) in buttressing the relevance of asset structure to positively impact firm value posits that disclosure of unknown previously private information about firm assets to investors makes the firm better off when it disposes them and uses as collateral good quality assets while maintaining poor quality assets in its books and fund it with deposits. The study thus emphasizes the importance of asset structure and also the suitability of securitization in transforming the asset structure to optimize the value of the firm.

The debate on asset composition is exacerbated by the mixed result found by different studies. Due to these empirical contradictions it remains unclear how asset structure of firms affects their financial performance. Considering the importance of assets to the firm, its relationship to the success of the firm has been a subject of as much rigorous research as there has been no consensus. On one hand some authors propose a negative relation of asset to profitability and earnings while in another breath some others propose a positive relation. These debates are exacerbated by other studies which argue that the type of assets relate differently with profitability. These arguments motivate further studies. In a period of slow economic growth and declining purchasing power as currently being witnessed in Nigeria it is interesting to know the nature of relationship of different spectrums of assets to earnings.

In Nigeria scant studies have been carried out on asset composition and profitability of firms. Also, despite scarcity of studies on this area, the few studies were mainly on manufacturing firms without much consideration to other sub sectors of the Nigeria economy. It is well known that service industries without much investment in fixed assets sometimes produces higher earnings than manufacturing firms thus igniting the debate on the role that assets and its composition play on firm performance. Furthermore, most of the studies in Nigeria concentrate on accounting based method of performance measurements despite the numerous identified short comings of accounting measures of performance which is not only historical in nature but suffers from bias which may emanate from the latitude granted preparers of accounting statements in terms of choice of methods in addition to not reflecting the future earnings potentials of the firm. This study attempts to fill the gaps from prior studies and attempt to provide answer to the question of the role of asset composition on financial performance of firms factoring non only accounting measures as well as market based measures.

\section{Empirical Literature Review}

Capital structure theories constitute the spring board for the discussion of asset structure. Miller \& Modigliani (1958) suggested that capital structure is irrelevant to the firm but rather that assets of the firm determines its value. Departing from this notion is the pecking order theory which suggests that tangible assets impact the ability of the firm to securitize borrowed funds since firms with higher fixed assets value easily access funds when compared to firms with higher non-tangible assets. The argument is anchored on the ability of the firm to mitigate investment risks by easily disposing the tangible assets which may impact on performance. Studies also confirm higher borrowing increases firm performance and assets facilitating borrowing is perceived to correlate with firm performance. The relevance of asset is further espoused by Campello \& Giambona (2010) when they averred that firms cannot borrow money without a strong assets structure and creditors prefer the tangible assets when they decide to lend money to others. Trade off theory postulated by Myers (1984) posit the tax advantage enjoyed by leverage firm and that this enhances performance. It follows from this line of argument that since assets facilitate borrowing by providing the needed collateral, tangible assets correlate with performance mainly because higher assets support higher borrowing with the attendant tax advantage which impacts positively on performance. Koralun-Bereźnicka (2013) suggested that high current assets lower short-term debts while high tangible assets support higher debts and this by extension imply reduced risk of bankruptcy cost and improved performance

Dong et al. (2012) studied the level of fixed assets and risk-adjusted performance of firms in China and observed that firms with high fixed assets and overhead expenses and covered by preferential tax policies in China are associated with lower risk-adjusted performance. Ansari \& Gowda (2017) in a study of Bombay Stock Exchange between 2007 and 2016 found that the relationship of asset intensity, proxied by fixed asset, and 
financial performance is negative and significant. Pouraghajan, Malekian, Emamgholipour, Lotfollahpour, \& Bagheri (2012) studied Iranian firms and confirmed significant positive relationship of non-current assets with return on assets (ROA) and return on equity (ROE). Michaux \& Mon (2014) using a panel of single-segment firms observed that Tobin's Q of firms with higher non-current assets are less affected by credit crunches and recessions, which confirm the intuition that lower non-current asset intensity may have a negative impact on firm value in bad aggregate states. Demir (2005) examined 172 Turkish firms from 1993 to 2003 to determine the nature of the relationship between fixed assets and profitability. He concluded that increasing short-term financial investments significantly reduce the negative effects of risk, volatility, and higher interest rates while increased uncertainty, country risk and real interest rates have significant negative effect on profitability. Abbas, Bashir, Manzoor \& Akram (2013) in a study of Pakistani firms found non-current asset does not have significant relationship with performance. $\mathrm{Li}$ (2004) examined the association of fixed assets, future profitability and returns on equity of firms between 1962 and 2002. The result showed a significant negative association between investment and future profitability. Zeitun \& Tian (2007) observed that non-current assets relate negatively and significantly with firms' performance. Dhillon \& Vachhrajani (2012) examine the impacts of operational efficiency on corporate profitability of Gujarat Industries Power Company Limited (GIPCL), for the period 2005 to 2010 using activity ratios. The study confirmed an insignificant positive correlation between operational efficiency and overall profitability. The study by Mawih (2014) on manufacturing firms listed on Muscat Securities Market (MSM), for the period 2008-2012 showed that the non-current assets had impact on ROE but not on ROA. It also concluded that current assets had no impact on ROE and ROA. Mwangi \& Birundu (2015) studied small and medium-sized enterprises in Kenya and the result showed an insignificant relationship of non-current asset and asset turnover on financial performance. Iqbal \& Mati (2012) examined the relationship of non-current assets and firms' profitability of non-financial firms using multiple regression analysis and found that there is an association between them. Kotšina \& Hazak (2012) examined 8,074 firms in six European Union (EU) countries for the period from 2001 to 2009 to determine the impact of investment intensity measured by the percentage of fixed assets to total assets and its relationship with return on assets. The study indicates that there is no strong negative or positive effect of investment intensity on future rate of return on assets. Azadi (2013) examined the effects of changes in assets (fixed and current) on operating earnings in the Tehran Stock Exchange. Results showed positive and significant effect of changes in the co-efficient of variation of fixed asset composition on operating earnings of food and metal industries while the coefficient of variation of current assets did not have a significant effect on operating earnings for Chemical industries, indicating that industry specific factors could influence results. Another result of the study suggests that asset structure changes make significant difference on operating earnings among different industries.

Okwo, Okelue, \& Nweze (2012) assessed the impact of a company's investment in fixed assets on its operating profit margin using sample for firms in the brewery sector in Nigeria for the period 1999 to 2009. The study concluded that there is a positive relationship between the variables, but it is not statistically significant hence the result did not suggest any strong positive impact of investment in fixed assets on the operating profit of brewery firms in Nigeria. Ishmael \& Kehinde (2013) assessed the impact of current assets on profits of Ajaokuta Iron and Steel firm between 2001 and 2010 and the result indicate that high proportion of current assets increases profitability. Olatunji et al. (2014) examined the effect of investment in fixed assets on profitability of selected Nigerian banks for the period 2000-2012. Study confirmed positive significant relations of non-current assets and long-term investments with net profit of Nigerian Banks. Reyhani (2012) measures the effect of assets structure on the performance of firms listed on Tehran Stock Exchange (TSE). The result of the study revealed that the fixed assets have a significant positive effect on earnings before interest and tax (EBIT). The study equally confirmed that the result of the effect of fixed assets on EBIT differ across industries. Zheng, Sheng \& NuoZhi (2013) carried out a study on the relations of optimal allocation of asset structure and business performance and concluded that asset structure research had more application value and has significant meaning in determining the financial performance. Hanran Li \& Wenzhou Wang (2014) observed that intangible assets; research and development, has significant effect on financial performance in contrast to employee benefit expense which does not.

\section{Conceptual Framework Asset Composition}

The composition of Assets of a firm has been x-rayed by diverse authors. According to ZhengSheng \& NuoZhi (2013), asset composition is the allocation of resources differently through division into turnover assets, production assets and wasting assets. Koralun-Bereźnicka (2013) described asset composition as a combination of the various asset components identified as financial fixed assets, tangible fixed assets; current assets; and current investments and cash in hand and at bank. A similar approach is taken by Schmidt (2014), which also classify assets into current assets; long term investments and funds; property, plant and equipment; intangible assets; and other assets. On the other hand, Mawih (2014) categorized assets into fixed and current assets. ZhengSheng \& NuoZhi (2013) contends that assets combination is significant in creating corporate value and avoiding risks. The structure of asset according to Syamsudin (2007) is the ascertainment of allocation of funds to each sub-division of asset both in 
current or non-current form. Asset composition reflects the financial decisions of management to allocate corporate resources to various fixed or non-current assets and to current assets with the aim of maximizing financial performance and firm value. The decision on the asset composition considers such factors as the business expansion plans, technological innovation, borrowing plans, tax incentives, risk appetite and industry asset capitalization requirements.

\section{Financial Performance}

According to Neely, Gregory \& Platts (1995), performance measurement involve the transfer of the complex reality of performance in organized symbols, that can be related and relayed under the same circumstances. It requires evaluating the actions, efficiency and effectiveness of an entity, persons or groups (Connolly, Conlon, \& Deustch, 1980; Hitt, 1988; Zammuto, 1984). Performance measurement can be in terms of financial performance and non-financial performance measures however this study focuses on the former. The Indonesian Institute of Accountants (2007) posits that financial performance means the firm's ability to manage and control resources. Sawir (2008) defines financial performance as a condition reflecting firm's position or assessed goals and standards. According to Bora (2008), financial performance imply firm's ability to generate new resources from day to day operations over a given period. Financial performance enhances shareholders' wealth and profit making which are among the major objectives of a firm (Pandey, 2005). Financial performance therefore is an evaluation approach to determining the extent of firm efficiency in deployment of resources towards the creation of additional value to stakeholders

\section{Accounting vs Market based Performance Measure}

According to Lebas (1995) there are two approaches to performance measurement namely: accounting and marketbased methods. The formulation of the market-based method which recognizes the equity and debt costs arose from the recognition of the inadequacies of accounting-based methods. The use of accounting-based criteria in financial performance evaluations is accepted as an effective assessment method of firms' profitability in comparison with benchmark rate of return which is equal to the risk adjusted weighted average cost of capital. The accounting methods used in short term financial performance evaluations are return on assets, return on investment, earnings per share, return on sales, return on capital employed, return on equity, dividend yield, expenses to assets, sales to assets, price earnings ratio, cash to assets, labor productivity, operation profit, market to book value, profit margin, growth in sales, cost of capital, log of market capitalization, critical business return on assets, operating cash flow, market value added, return on revenue, output per staff etc. Accounting based methods of performance assessment has suffered various criticisms and its drawbacks are tremendous despite being widely deployed by assessors of performance. First, it is argued that profitability relates to past events and partially estimates future events through depletion, depreciation and amortization. It is also argued that accounting standards impose limitations on preparers of financial statements implying that profit evaluation and financial reporting is impacted by accounting practice through the various methods used in valuation of assets and intangibles. Thirdly, accounting based performance measure is assumed to produce inaccurate and subjective accounting numbers due to the latitude provided to managers by accounting standards on choice of methods. This creates opportunity for managers to manipulate accounting figures. The use of alternative accounting methods impact on earnings and can materially alter reported numbers while cash flows and economic value remain constant. This reduces reliability of results when compared with different firms and in different time horizon within the same firm. It can also cause moral hazards by inducing managers to manipulate accounting reports. Inflation can also influence accounting numbers because the denominator and numerator do not add up to homogenous number thus while sales are current, capital is not. Another disadvantage of accounting-based method of performance evaluation is that it ignores the cost of capital invested both in terms of risk free rate and risk premium. This creates ambiguity as earnings maximization does not take cognizance of capital deployed to create the earnings and may also not translate to maximization of shareholders value.

The market-based measurement techniques projects into the future and reflects the expectations of the shareholders concerning the firm's future performance, which has its basis on previous or current performance (Wahla,ShahSyed \& Hussain, 2012; Shan \& McIver Ron, 2011; \& Ganguli \& Agrawal, 2009). According to Bozec, Dia \& Bozec, (2010) Tobin's Q is a traditional measure of expected long-run performance of the firm. The employment of market value of equity may present the firm's future growth opportunities which could stem from factors exogenous to managerial decisions and this is indicated by the firm level Tobin's Q (Shan \& McIver, 2011; Demsetz \& Villalonga, 2001). In addition, a high Tobin's Q ratio shows success in a way that the firm has leveraged its investment to develop the company that is valued more in terms of its market-value compared to its book-value (Kapopoulos \& Lazaretou, 2007). This study uses both accounting and market-based performance measures in assessing the relationship between asset structure and financial performance. 
Figure 1.

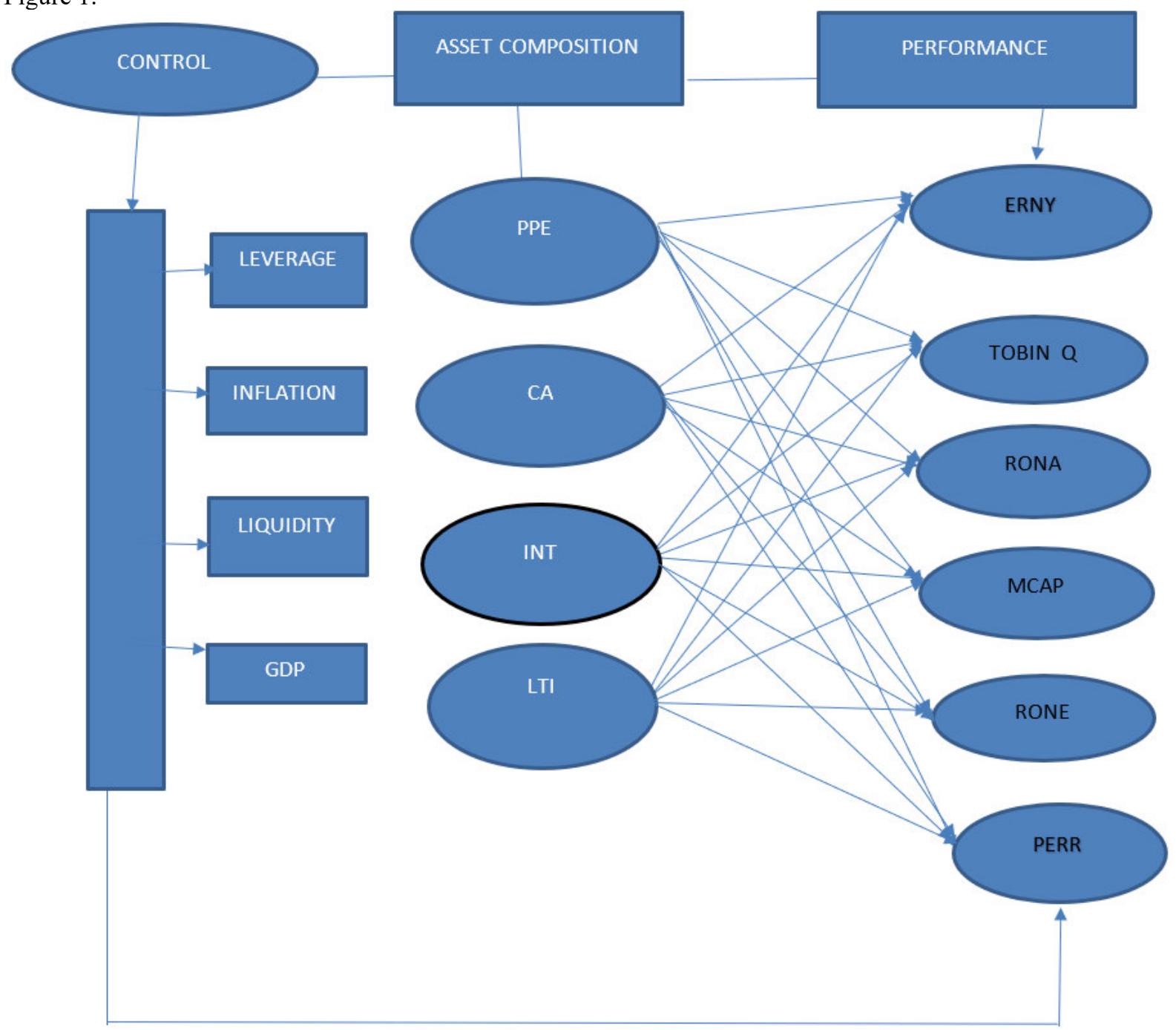

\section{Conceptual model of the nexus of Asset Composition with Accounting and Market-Based Performance}

\section{METHODOLOGY}

\section{Sampling, Data and Variables}

The population of the study consist of all firms listed on the exchange. We adopted census method of sampling to select firms with complete data from insurance, banking, food and beverage and other subsector of manufacturing and a total of fifty firms were selected. The raw secondary data used in this study are essentially financial accounting data obtained from annual reports and financial statements published by firms in insurance, banking and manufacturing sectors in their website and the other information were sourced from the Nigerian Stock exchange (NSE) Fact Book over the period of covered by the study (2013 to 2017).

\section{Independent variable}

The components of asset structure that comprise the independent variables in the study are property, plant and equipment; current assets; intangible assets; and long-term investments and funds following Schmidt (2014). These variables were standardized by computing the ratio of each independent variable to the total assets to account for differences in the sizes of the firms.

\section{Dependent Variable}

The dependent variable of financial performance, was broken down into various indicators namely Tobin's $Q$, return on assets, return on equity, price earnings ratio and market capitalization, profitability (profit margin), and liquidity (current ratio). 


\section{Control variable}

The control variable in this study is growth rate of GDP and inflation rate over study period as published by Federal Office of Statistics $(F O S)$, liquidity measured by current asset divided by current liabilities, and leverage

Table 4.0

Measurement of Variables

\begin{tabular}{|l|l|l|}
\hline Variables & $\begin{array}{l}\text { Represented } \\
\text { by }\end{array}$ & Measurement of Variables \\
\hline Independent: & $C A$ & Current asset divided by Total Asset \\
\hline Current asset & $P P E$ & PPE divided by Total Asset \\
\hline $\begin{array}{l}\text { Plant Property and } \\
\text { Long-term Investment }\end{array}$ & $L T I$ & Long term investment divided by Total Asset \\
\hline Intangible asset & $I N T$ & Intangible Asset divided by Total Asset \\
\hline Dependent: & & \\
\hline Price Earnings Ratio & $P E R$ & Market price per share divided by Earnings per share \\
\hline Returns on Asset & $R O A$ & Earnings before tax divided by Average total asset \\
\hline Returns on Equity & $R O E$ & Earnings before tax divided by Shareholder's funds \\
\hline Earnings Yield & $E R N Y$ & Earnings per share divided by market price per share \\
\hline Market Capitalization & $M C A P$ & Market price multiplied by outstanding shares \\
\hline Tobin's Q & $T O B I N Q$ & $\begin{array}{l}\text { We adopt Chung and Pruitt's approximating formulation of } \\
\text { Tobin's Q }=\text { MVE + PS + DEBT/TA }\end{array}$ \\
\hline Control: & & \\
\hline Inflation & $I N F$ & As published by Federal office of statistics \\
\hline Leverage & $L E V$ & Total debt/Equity \\
\hline Liquidity & $L I Q$ & Current asset/current liabilities \\
\hline Gross domestic product & $G D P$ & As published by federal office of statistics \\
\hline
\end{tabular}

Table 4.0 describes the variables, their representative abbreviations and their method of computation.

\section{Model Specification}

$\begin{array}{lccc}P E R= & z_{0}+z_{1} P P E+z_{2} C A+z_{3} I N T+z_{4} L T I+z_{5} G D P+z_{6} I N F+z_{7} L I Q++z_{8} L E V+U_{1}, t & \text { (i) } \\ R O A= & y_{0}+y_{1} P P E+y_{2} C A+y_{3} I N T+y_{4} L T I+y_{5} G D P+y_{6} I N F+y_{7} L I Q+y_{8} L E V+U_{2, t} \\ R O E= & x_{0}+x_{1} P P E+x_{2} C A+x_{3} I N T+x_{4} L T I+x_{5} G D P+x_{6} I N F+x_{7} L I Q+x_{8} L E V+U_{3}, t & \text { (ii) } \\ E R N Y= & \alpha_{0}+\alpha_{1} P P E+\alpha_{2} C A+\alpha_{3} I N T+\alpha_{4} L T I+\alpha_{1} G D P+\alpha_{2} I N F+\alpha_{3} L I Q+\alpha+\alpha_{4} L E V+U_{4, t} & \text { (iii) } \\ M C A P= & \beta_{0}+\beta_{1} P P E+\beta_{2} C A+\beta_{3} I N T+\beta_{4} L T I+\beta_{5} G D P+\beta_{6} I N F+\beta_{7} L I Q+\beta_{8} L E V+U_{5, t} \text { (iv) } \\ T O B Q= & w_{0}+w_{1} P P E+w_{2} C A+w_{3} I N T+w_{4} L T I+w_{5} G D P+w_{6} I N F+w_{7} L I Q+w_{8} L E V+U_{6}, t & \text { (v) }\end{array}$

Where earnings yield is $E R N Y$, return on assets is $R O A, R O E$ is return on equity, PER is price earnings ratio TOBN is Tobin's $\mathrm{Q}$ and $M C A P$ is market capitalization. On the other hand, PPE is property, plant and equipment, , CA is current asset, $I N T$ is intangible asset, $L T I$ is long term investments. $L E V$ is leverage, $L I Q$ is liquidity, GDP is gross domestic product, INF is inflation while: $U i, t$ is Error term, $\alpha_{0}, \beta_{0}, w_{o}, x o, y o, z o=$ intercepts and $\alpha_{l}, \beta_{l}, w_{l}$, $x 1, y 1$ and $z 1=$ slope coefficients. From equations, $v i$ to it is expected that $\alpha_{1}, \beta_{1}, w_{1, X 1}, y 1$ and $z 1>0$. It is also expected that an increase in PPE, $C A, I N T$ and $L T I$ increases return on asset, return on equity, earnings yield, price earnings ratio, market capitalization and Tobin's $Q$ respectively.

\section{RESULT AND DISCUSSION OF FINDINGS}

The objective of the study was to ascertain the relationship between various asset components of insurance, banking and manufacturing firms and market and accounting performance. The Result of data analysis is presented in Table 4.1 to Table 4.8. A discussion of the findings follows each result. 
Table 4.1. : Descriptive Statistics

\begin{tabular}{|c|c|c|c|c|c|c|}
\hline Variables & Mean & $\begin{array}{c}\text { Standard } \\
\text { Deviation }\end{array}$ & Maximum & Minimum & Jarque-Bera & Prob. \\
\hline$C A$ & 1.135384 & 3.671377 & 56.5694 & -1.1171 & 470623 & 0.000 \\
\hline$P P E$ & 0.740125 & 1.2592 & 13.0238 & 0.0006 & 15385.03 & 0.000 \\
\hline$L T I$ & 0.192051 & 0.482651 & 5.4255 & 0 & 61917.33 & 0.000 \\
\hline$I N T$ & 0.034805 & 0.194505 & 1.700148 & 0 & 25344.04 & 0.000 \\
\hline$L I Q$ & 2.433605 & 5.855432 & 56.56938 & -1.08479 & 30047.4 & 0.000 \\
\hline$L E V$ & 2.322463 & 4.291241 & 57.88329 & -9.26968 & 136945.7 & 0.000 \\
\hline$I N F L A$ & 11.50224 & 3.733893 & 16.5 & 8.06 & 38.85564 & 0.000 \\
\hline$G D P$ & 2.831037 & 2.891629 & 6.22 & -1.6 & 21.38984 & 0.000 \\
\hline$R O A$ & 0.527211 & 3.389683 & 34.53011 & -0.43179 & 62971.74 & 0.000 \\
\hline$R O E$ & 1.033473 & 7.977713 & 85.58345 & -0.58014 & 91335.39 & 0.000 \\
\hline$P E$ & 40.09902 & 521.5527 & 8100 & -64.3125 & 567054.1 & 0.000 \\
\hline$E R N Y$ & 0.520332 & 17.87552 & 57.06118 & -240.793 & 192724.9 & 0.000 \\
\hline$M C A P$ & $1.74 \mathrm{E}+11$ & $5.17 \mathrm{E}+11$ & $3.73 \mathrm{E}+12$ & 3435879 & 8062.049 & 0.000 \\
\hline$T O B I N Q$ & 169343.3 & 1541281 & 20605801 & 0.566996 & 187949 & 0.000 \\
\hline
\end{tabular}

Source: Eviews 10.

Table 4.1 shows the descriptive statistics for the variables and as observed, $C A$ has mean of 1.135 with a standard deviation of 3.67 indicating the extent of dispersion from the mean. $P P E$ has mean value of 0.740 with a standard deviation of 1.25 . The mean for $L T I$ is 0.192 with standard deviation of 0.483 . INT has mean of 0.034 with standard deviation of 0.195 . The mean for $L I Q$ is 2.43 with standard deviation of 5.855. $L E V$ has mean value of 2.32 with standard deviation of 4.291. The mean for INFLA is 11.502 with standard deviation of 3.73. The mean for GDP is 2.83 billion with standard deviation of 2.89. ROA has mean of 0.5272 with standard deviation of 3.389. The mean for PER is 40.099 with standard deviation of 521.553. ERNY has mean value of 0.520 with standard deviation of 17.875 . The mean for $M C A P$ is $1.74 \mathrm{E}+11$ with standard deviation of $5.17 \mathrm{E}+11$. The mean for $T O B I N Q$ is 169343.3 with standard deviation of 1541281 . The Jacque-bera probability values for all the variables are all more than 0.05 which suggest the unlikely presence of outliers in the distribution and the variables follows a normal distribution pattern.

\section{Table 4.2. Correlation Statistics}

\begin{tabular}{|c|c|c|c|c|c|c|c|c|c|c|c|c|c|c|}
\hline Variables & $C A$ & $P P E$ & $L T I$ & $I N T$ & $L I Q$ & $L E V$ & INFLA & $G D P$ & $R O A$ & $R O E$ & $P E$ & $E R N Y$ & MCAP & TOBINQ \\
\hline$C A$ & 1 & 0.66 & & & & & & & & & & & & \\
\hline$P P E$ & 0.6598 & 1 & & & & & & & & & & & & \\
\hline LTI & -0.051 & 0.028 & 1 & & & & & & & & & & & \\
\hline$I N T$ & -0.009 & 0.238 & -0.041 & 1 & & & & & & & & & & \\
\hline$L I Q$ & 0.5884 & 0.295 & -0.042 & -0.041 & 1 & & & & & & & & & \\
\hline$L E V$ & -0.013 & -0.12 & -0.016 & -0.031 & -0.02 & 1 & & & & & & & & \\
\hline INFLA & 0.074 & 0.017 & -0.061 & 0.0023 & 0.075 & 0.1012 & 1 & & & & & & & \\
\hline$G D P$ & -0.103 & -0.04 & 0.0335 & -0.001 & -0.11 & -0.053 & -0.88 & 1 & & & & & & \\
\hline$R O A$ & 0.035 & 0.004 & 0.0694 & 0.0097 & 0.007 & -0.029 & -0.09 & 0.075 & 1 & & & & & \\
\hline$R O E$ & -0.015 & -0.054 & 0.0707 & -0.015 & -0.021 & -0.012 & -0.08 & 0.0675 & 0.97084 & 1 & & & & \\
\hline PER & -0.009 & -0.004 & -0.026 & -0.005 & -0.021 & 0.0391 & 0.071 & -0.096 & -0.00733 & -0 & 1 & & & \\
\hline ERNY & 0.0037 & 0.029 & 0.0324 & $-5 \mathrm{E}-04$ & 0.033 & 0.0644 & -0.04 & 0.0249 & 0.09739 & 0.083 & -0.002 & 1 & & \\
\hline MCAP & 0.0101 & 0.264 & 0.04 & 0.2685 & -0.032 & -0.017 & -0.01 & 0.0146 & 0.01531 & -0.03 & 0.0647 & 0.007 & 1 & \\
\hline TOBINQ & 0.0185 & 0.145 & -0.014 & -0.017 & -0.008 & -0.04 & -0.03 & 0.0217 & 0.0162 & -0.01 & -0.005 & -0.009 & 0.601 & 1 \\
\hline
\end{tabular}

Source: Eviews 10.

Table 4.2 presents the correlation results and as observed and particularly, the study is concerned with the correlations between the firm performance measures and the asset composition measures. As observed, $R O A$ is correlated with the following variables; $C A(\mathrm{r}=0.035), P P E(\mathrm{r}=0.004), L T I(\mathrm{r}=0.694), I N T(\mathrm{r}=0.0097), L I Q$ $(\mathrm{r}=0.007), L E V(\mathrm{r}=0.029), I N F L A(\mathrm{r}=-0.09)$ and $G D P(\mathrm{r}=0.075) . R O E$ is correlated with $C A(\mathrm{r}=-0.015), P P E(\mathrm{r}=-$ $0.054), L T I(\mathrm{r}=0.0707), I N T(\mathrm{r}=-0.015), L I Q(\mathrm{r}=-0.021), L E V(\mathrm{r}=-0.012), I N F L A(\mathrm{r}=-0.08)$ and GDP $(\mathrm{r}=0.97) . P E R$ is correlated with $C A(\mathrm{r}=-0.009), P P E(\mathrm{r}=-0.004), L T I(\mathrm{r}=-0.026), I N T(\mathrm{r}=-0.005), L I Q(\mathrm{r}=-0.021), L E V(\mathrm{r}=-0.0391)$, INFLA $(\mathrm{r}=-0.071)$ and $G D P(\mathrm{r}=-0.096) . E R N Y$ is correlated with $C A(\mathrm{r}=0.0037), P P E(\mathrm{r}=0.029), L T I(\mathrm{r}=-0.0324)$, $I N T(\mathrm{r}=-5 \mathrm{E}-04), L I Q(\mathrm{r}=0.033), L E V(\mathrm{r}=0.0644), I N F L A(\mathrm{r}=-0.04)$ and $G D P(\mathrm{r}=0.0249) . M C A P$ is correlated with $C A(\mathrm{r}=0.010), P P E(\mathrm{r}=0.264), L T I(\mathrm{r}=0.04), I N T(\mathrm{r}=0.269), L I Q(\mathrm{r}=-0.032), L E V(\mathrm{r}=-0.017), I N F L A(\mathrm{r}=0.01)$ and $G D P(\mathrm{r}=0.0146)$ and finally TOBINQ is correlated with $C A(\mathrm{r}=0.0185), P P E(\mathrm{r}=0.145), L T I(\mathrm{r}=-0.014)$, INT $(\mathrm{r}=-$ $0.017), \operatorname{LIQ}(\mathrm{r}=-0.008), \operatorname{LEV}(\mathrm{r}=-0.04), I N F L A(\mathrm{r}=-0.03)$ and $G D P(\mathrm{r}=0.0217)$. 
Result of the Relationship of Asset Components and Price Earnings Ratio

Model 1:

$P E R=\quad z_{0}+z_{1} P P E+z_{2} C A+z_{3} I N T++z_{4} L T I+z_{5} G D P+z_{6} I N F+z_{7} L I Q++z_{8} L E V+U_{1, t}$

Table 4.3. Asset Composition and $P E R$ Fixed Effects Regression

\begin{tabular}{|c|c|c|c|c|}
\hline Variable & Coefficient & Std. Error & t-Statistic & Prob. \\
\hline$C$ & 36.593 & 3.8107 & 9.603 & $0.000^{*}$ \\
$C A$ & 0.8490 & 0.5478 & 1.550 & 0.123 \\
$P P E$ & -3.621 & 2.539 & -1.4259 & 0.156 \\
$L T I$ & 1.863 & 0.757 & 2.461 & $0.015^{*}$ \\
$I N T$ & 19.352 & 7.41749 & 0.609 & $0.009^{*}$ \\
LIQ & 0.019 & 0.031 & 0.788 & 0.530 \\
LEV & 0.071 & 0.0901 & 0.816 & 0.432 \\
$I N F L A$ & 0.231 & 0.283 & 1.124 & 0.415 \\
GDP & 0.4047 & 0.360 & & \\
\hline$R^{2}=0.29477 \quad$ Adjusted $R^{2}=0.076302$, & $F$-stat $=13.493 \quad P(f)=(0.011) . D . W=1.8$ & \\
Hausman=0.022 & & &
\end{tabular}

Source: Eviews 10.*sig@, 5\%,**sig@10\%

Table 4.3 show the regression results examining the impact of Asset composition on price earning ratio $(P E R)$. The $\mathrm{R}^{2}$ is $29.48 \%$ with an adjusted value of $7.6 \%$. The F-stat of 13.493 (p-value $=0.00$ ) which is significant at $5 \%$ and suggest that the hypothesis of a significant linear relationship between the dependent and independent variables cannot be rejected. It is also indicative of the joint statistical significance of the model. The white adjusted standard errors were employed to control for potential heteroskedasticity in the estimation and hence the estimation results are free from heteroskedasticity. The Durbin Watson $(D . W)$ value of 1.8 suggest that the presence of serial correlation between the errors is unlikely in the model. The analysis of coefficients reveals that $C A$ has a positive $(0.1572)$ effect on PE but not statistically significant at $5 \%(\mathrm{p}=0.123), P P E$ shows a non-statistically significant at $5 \%(p=0.156)$ impact on PE with a negative coefficient $(-3.621)$. The effect of LTI is positive $(0.015)$ and statistically significant $(\mathrm{p}=0.015)$ at $5 \%$. The effect of $I N T$ on is also positive (19.352) and statistically significant $(\mathrm{p}=0.009)$ at $5 \% . L I Q, L E V, I N F$ and GDP all have positive effects on PER with coefficients of $0.019,0.071,0.231$ and 0.4047 respectively though none was statistically significant at $5 \%$.

\section{Hypotheses}

$\mathrm{H}_{01}$ : There is no significant relationship between Asset Composition and Price earnings ratio

$\mathrm{H}_{\mathrm{O} 1} \mathrm{a}$ : There is no significant relationship between current Assets and Price earnings ratio

The coefficient is positive 0.8490 denoting a positive relationship between current asset and price earnings ratio. The $p$-value is $0.123>0.05$ implying an insignificant relationship of current asset to Price earnings ratio. Based on p-values we accept the null hypothesis that there is no significant relationship between current asset and price earnings ratio

$\mathrm{H}_{01}$ b: There is no significant relationship between Plant Property and Equipment and Price earnings ratio The co-efficient is negative -3.621 showing a negative relationship of $P P E$ with Price earnings ratio. $P$-value is $0.156>0.05$ denoting an insignificant relationship. Based on findings we accept the null hypothesis that there is no significant relationship between $P P E$ and $P E R$

$\mathrm{H}_{\mathrm{O} 1} \mathrm{c}$ : There is no significant relationship between Long Term Investment and Price earnings ratio

The coefficient is positive 1.863 denoting a positive relationship between long term Investment and price earnings ratio. The $p$-value is $0.015<0.05$ implying significant relationship of $L T I$ to Price earnings ratio. Based on $\mathrm{p}$-values we reject the null hypothesis that there is no significant relationship $L T I$ and price earnings ratio and confirm positive significant relationship of $L T I$ with $P E R$.

$\mathrm{H}_{\mathrm{O} 1} \mathrm{~d}$ : There is no significant relationship between Intangible Asset and Price earnings ratio

The coefficient is positive 19.352 denoting a positive relationship between intangible asset and price earnings ratio. The p-value is $0.009<0.05$ implying a significant relationship of Intangible asset to Price earnings ratio. Based on p-values we reject the null hypothesis that there is no significant relationship between current asset and price earnings ratio and confirm significant positive relationship between the variables

From Model I and table 4.3 we examine the relation between the components of assets; current asset to total asset $(C A / T A), P P E / T A, L T I / T A$ and INT/TA and Price earnings ratio. The study confirmed a positive not statistically significant relationship of CA with price earnings ratio and a negative statistically relationship of Plant Property and Equipment with PER. Also, Long term investment and Intangible assets have a statistical significant and positive relationship with PER. This finding agrees with Azadi (2013) which observed that the coefficient of variation of fixed assets has positive and significant effect on operating earnings This could be explained that an increase in investment is likely to increase earnings and investors' confidence hence the positive relationship. Intangibles such as goodwill and good market perception of the brand is likely to have an impact on the share 
prices. This finding deviate from the findings of Okwo, Okelue \& Nweze (2012) that found no strong relation of LTI with profits. The other variables inflation, liquidity, leverage and gross domestic product all have positive and statistical insignificant relationship with PER. The price/earnings ratio (PER) is used in determining whether shares are "correctly" valued in relation to one another. But the PER does not in itself indicate whether the share is a bargain. The PER depends on the market's perception of the risk and future growth in earnings. A firm with a low PER indicates that the market perceives it as higher risk or lower growth or both as compared to a company with a higher PER. The PER of a listed firm's share is the result of the collective perception of the market as to how risky the firm is and what its earnings growth prospects are in relation to that of other companies. Investors use the PER to compare their own perception of the risk and growth of a firm against the market's collective perception of the risk and growth as reflected in the current PER. If investors believe that their perception is superior to that of the market, they can make the decision to buy or sell accordingly

\section{Result of the Relationship of Asset Components and Return of Assets}

Model 2:

$R O A=y_{0}+y_{1} P P E+y_{2} C A+y_{3} I N T+y_{4} L T I+y_{5} G D P+y_{6} I N F+y_{7} L I Q++y_{8} L E V+U_{2}, t$

Table 4.4. Asset Composition and $R O A$ Fixed Effects Regression

\begin{tabular}{|c|c|c|c|c|}
\hline Variable & Coefficient & Std. Error & t-Statistic & Prob. \\
\hline C & 0.507 & 0.1948 & 2.608 & $0.0098^{*}$ \\
CA & 0.0412 & 0.0037 & 11.059 & $0.000^{*}$ \\
PPE & 0.0597 & 0.0159 & 3.7667 & $0.0002^{*}$ \\
ITI & 0.0489 & 0.0753 & 0.649 & 0.5174 \\
LIQ & 0.325 & 0.0631 & 5.146 & $0.000^{*}$ \\
LEV & -0.002 & 0.0007 & -2.536 & $0.012^{*}$ \\
INFLA & 0.002 & 0.001 & 1.181 & 0.2391 \\
GDP & -0.011 & 0.014 & -0.819 & 0.4133 \\
$R^{2}=0.787946 \quad$ Adjusted $R^{2}=0.723653 \quad F$-statistic=12.25558 $P(f$-stat $)=0.000 . D . W=1.9$ & 0.5582 \\
Hausman $(p$-value $=0.001$ & 0.0098 & & \\
\hline
\end{tabular}

Source: Eviews 10.*sig@ @\%,**sig@10\%

Table 4.4 show the regression results examining the effect of asset composition on $R O A$. The $R^{2}$ is $78.79 \%$ with and adjusted value of $72.36 \%$. The $F$-stat of $12.25(p$-value $=0.00)$ which is significant at $5 \%$. The white adjusted standard errors was employed to control for potential heteroskedasticity in the estimation and hence the estimation results are free from heteroskedasticity. The Durbin Watson $(D . W)$ value of 1.9 suggest that the presence of serial correlation between the errors is unlikely in the model. The analysis of coefficients reveals that $C A$ has a positive (0.0412) effect on $P E R$ and statistically significant at $5 \%(p=0.000), P P E$ also has a positive effect $(0.0597)$ and significant at $5 \%(p=0.000)$. The effect of $L T I$ is positive $(0.5174)$ though not statistically significant $(p=0.5174)$ at $5 \%$. The effect of $I N T$ is also positive $(0.325)$ and statistically significant $(\mathrm{p}=0.000)$ at $5 \%$. $L E V$, $I N F$ and $G D P$ are all statistically insignificant at $5 \%$ with coefficient of $0.2391,0.4133$ and 0.5582 respectively while $L I Q$ displays a negative coefficient (-0.002) and significant at 5\%

\section{Ho2: There is no significant relationship between Asset Composition and $\underline{R O A}$}

$\mathrm{H}_{\mathrm{O} 2} \mathrm{a}$ : There is no significant relationship between current Assets and Returns on Asset

The coefficient is positive 0.0412 denoting a positive relationship between current asset and $R O A$. The p-value is $0.000<0.05$ implying significant relationship of current asset to $R O A$. Based on p-values we reject the null hypothesis that there is no significant relationship between current asset and $R O A$ and confirm significant relationship amongst the variables

$\mathrm{H}_{02} \mathrm{~b}$ : There is no significant relationship between Plant Property and Equipment and $R O A$

The co-efficient is positive 0.0597 showing a positive relationship of $P P E$ with $R O A$. $\mathrm{P}$-value is $0.0002<0.05$ denoting significant relationship. Based on findings we reject the null hypothesis that there is no significant relationship between $P P E$ and $R O A$.

$\mathrm{H}_{\mathrm{O} 2} \mathrm{c}$ : There is no significant relationship between Long Term Investment and $R O A$

The coefficient is positive 0.0489 denoting a positive relationship between long term Investment and $R O A$. The pvalue is $0.05174>0.05$ implying no significant relationship of $L T I$ to $R O A$. Based on p-values we accept the null hypothesis that there is no significant relationship between $L T I$ and $R O A$.

$\mathrm{H}_{\mathrm{O} 2} \mathrm{~d}$ : There is no significant relationship between Intangible Asset and $R O A$

The coefficient is positive 0.325 denoting a positive relationship between intangible asset and $R O A$. The p-value is $0.000<0.05$ implying a significant relationship of Intangible asset to $R O A$. Based on p-values we reject the null hypothesis that there is no significant relationship between current asset and $R O A$ and confirm significant positive relationship between the variables. 


\section{Discussion}

From model 2 and table 4.4 we examine the relationship between asset composition and returns on asset. Current assets, Property Plant and Equipment, Long term Investments and Intangible Asset Significantly relates positively with $R O A$ implying that increases in any of the variables increases Returns on assets. This finding agrees with study by Reyhani (2012) which revealed fixed assets have a significant positive effect on EBIT and Ishmael \& Kehinde (2013) which indicate that high proportion of current assets increases profitability. This result also agrees with that of Iqbal \& Mati (2012) which concluded that there is an association between non-current asset and firm's profitability. Liquidity has a negative statistical significant effect on $R O A$ while $G D P$, Inflation and leverage have insignificant relationship. The implication is that macro-economic factors do not significantly affect returns on asset. However, an increase in liquidity reduces returns on assets. The reason is not farfetched as increase liquidity reduces amount of fund available for investment in fixed assets. There is normally a trade-off between amount of liquid cash held and amount invested.

\section{Result of the Relationship of Asset Components and Return on Equity \\ Model 3 \\ $R O E=x_{0}+x_{1} P P E+x_{2} C A+x_{3} I N T++x_{4} L T I+x_{5} G D P+x_{6} I N F+x_{7} L I Q+x_{8} L E V+U_{3}, t$}

Table 4.5. Asset Composition and ROE Fixed Effects Regression

\begin{tabular}{|c|c|c|c|c|}
\hline Variables & Coefficient & Std. Error & t-Statistic & Prob. \\
\hline$C$ & 1.0112 & 0.038 & 26.818 & $0.000^{*}$ \\
$C A$ & 0.0168 & 0.005 & 3.6739 & $0.000^{*}$ \\
PPE & -0.0492 & 0.011 & -4.3808 & $0.000^{*}$ \\
LTI & -0.0605 & 0.023 & -2.659 & $0.009^{*}$ \\
INT & 0.0754 & 0.039 & 1.936 & $0.054^{* *}$ \\
LIQV & -0.0028 & 0.0016 & -1.785 & $0.076^{* *}$ \\
INFLA & 0.0196 & 0.0028 & 7.0543 & $0.000^{*}$ \\
GDP & -0.0028 & 0.0031 & -0.915 & 0.361 \\
$R^{2}=0.529097 \quad$ Adjusted $R^{2}=0.386323 \quad$ F-statistic = 13.705844. P(f-stat $)=0.00 D . W=1.9$ & $0.007^{*}$ \\
Hausman=0.022 & 0.0082 & \\
\hline
\end{tabular}

Source: Eviews 10.*sig@ @\%,**sig@10\%

Table 4.5 show the regression results examining the impact of Asset composition on $R O E$. The $R^{2}$ is $52.91 \%$ with and adjusted value of $38.63 \%$. The $F$-stat of $13.71(\mathrm{p}$-value $=0.00)$ and significant at $5 \%$. The white adjusted standard errors was employed to control for potential heteroskedasticity in the estimation and hence the estimation results are free from heteroskedasticity. The Durbin Watson $(D . W)$ value of 1.9 suggest that the presence of serial correlation between the errors is unlikely in the model. The analysis of coefficients reveals that $C A$ has a positive (0.0168) effect on $R O E$ and statistically significant at 5\% ( $\mathrm{p}=0.000), P P E$ also has a negative effect $(-0.049)$ and significant at $5 \%(\mathrm{p}=0.000)$. The effect of $L T I$ is negative $(-0.0605)$ and statistically significant $(\mathrm{p}=0.000)$ at $5 \%$. The effect of INT is positive (0.0754) and statistically significant $(\mathrm{p}=0.054)$ at $10 \%$. LEV and GDP are both statistically significant at $5 \%$ with beta of 0.0196 and 0.008 respectively while $L I Q$ and $I N F$ display a negative coefficient of -0.00281 and -0.00283 respectively though only $L I Q$ is significant at $10 \%$.

\section{$\mathrm{H}_{03}$ : There is no significant relationship between Asset Composition and $\mathrm{ROE}$}

Hоза: There is no significant relationship between current Assets and Returns on Equity

The coefficient is positive 0.0168 denoting a positive relationship between current asset and $R O E$. The p-value is $0.000<0.05$ implying significant relationship of current asset to $R O E$. Based on p-values we reject the null hypothesis that there is no significant relationship between current asset and $R O E$ and confirm significant relationship amongst the variables

$\mathrm{H}_{03} \mathrm{~b}$ : There is no significant relationship between Plant Property and Equipment and $R O E$

The co-efficient is negative - 0.0492 showing a negative relationship of $P P E$ with $R O E$. P-value is $0.0000<0.05$ denoting significant relationship. Based on findings we reject the null hypothesis that there is no significant relationship between $P P E$ and $R O E$ and confirm significant relationship amongst the variable

$\mathrm{H}_{O 3} \mathrm{c}$ : There is no significant relationship between Long Term Investment and $R O E$

The coefficient is negative -0.0605 denoting a negative relationship between long term Investment and $R O E$. The p-value is $0.009>0.05$ implying no significant relationship of $L T I$ to $R O E$. Based on p-values we accept the null hypothesis that there is no significant relationship between $L T I$ and $R O E$.

$\mathrm{H}_{\mathrm{O} 3} \mathrm{~d}$ : There is no significant relationship between Intangible Asset and $R O E$

The coefficient is positive 0.0754 denoting a positive relationship between intangible asset and $R O E$. The p-value is $0.054>0.05$ implying insignificant relationship of Intangible asset to $R O E$. Based on p-values we accept the null hypothesis that there is no significant relationship between current asset and $R O E$ 


\section{Discussion}

In model three and table 4.5 we examine the relationship between asset composition and returns on Equity. Current assets and Intangible asset have significant statistical positive relationship with Returns on Equity implying that an increase in current asset and Intangible asset increases return on Equity. The finding agrees with that of Ishmael \& Kehinde (2013) which indicate that high proportion of current assets increases profitability. Intangibles assets such as good business name and goodwill will expectedly impact on profitability. Good current asset which enhances the liquidity of the firm implies that firms will be meeting maturing obligations as it falls due thus enhancing firm reputation. Conversely, PPE and Long-Term Investments have negative and statistical significant relationship with ROE implying increases in PPE and LTI reduces returns on Equity. The implication is that higher investments in PPE and LTI enhances the ability of the firm to securitize borrowing. Increase in borrowing reduces earnings available to equity holders as lenders rank higher than equity holders in time of liquidation. Also, interest payments reduce funds available to equity shareholders for distribution. This finding also contrasts with Okwo, Okelue \& Nweze (2012) which found no strong relation of investments in assets with earnings. At the Macro level inflation have insignificant negative relationship with ROE while GDP has significant positive relation with ROE. An increase in GDP increases Returns to shareholders while an increase in inflation though reduces returns to shareholders but it is insignificant. Increase GDP is a sign of stable economic outlook and a signal for boom. There is every likelihood that during period of increased GDP firms are likely to do better and returns to equity holders will increase during this period. Leverage on the other hand positively impact Returns on equity and liquidity negatively and insignificantly relates with returns on Equity. This result should be interpreted with care as Shareholding structure may have an impact on the result of our study. Also, the effect of leverage on ROE could be explained in terms of the tax advantage.

\section{Result of the Relationship of Asset Components and Earnings Yield} Model 4

$E R N Y=\alpha_{0}+\alpha_{1} P P E+\alpha_{2} C A+\alpha_{3} I N T++\alpha_{4} L T I+\alpha_{1} G D P+\alpha_{2} I N F+\alpha_{3} L I Q++\alpha_{4} L E V+U_{4}, t \quad-$ Table 4.6. Asset Composition and ERNY Fixed Effects Regression

\begin{tabular}{|c|c|c|c|c|}
\hline Variable & Coefficient & Std. Error & t-Statistic & Prob. \\
\hline$C$ & 0.7266 & 0.156087 & 4.655436 & $0.000^{*}$ \\
$C A$ & 0.0049 & 0.035123 & 0.139101 & 0.8895 \\
$P P E$ & -0.0424 & 0.115882 & -0.36587 & 0.7149 \\
$L T I$ & 0.3792 & 0.50292 & 0.753942 & 0.4518 \\
$I N T$ & -3.573 & 0.376717 & -9.48535 & $0.000^{*}$ \\
$L I Q$ & 0.0108 & 0.016882 & 0.636659 & 0.5251 \\
LEV & -0.0121 & 0.027467 & -0.43985 & 0.661 \\
$I N F L A$ & -0.0099 & 0.011023 & -0.90022 & 0.369 \\
$G D P$ & -0.0116 & 0.009588 & -1.20693 & 0.229 \\
\hline$R^{2}=0.655074$ & Adjusted $R=0.54 . F$-stat=16.231. $p(f$-stat $)=0.000 . D$. $W$ stat $=2.01$ & \\
Hausman=0.00 & & & \\
\end{tabular}

Source: Eviews 10.* *sig@ $@$ \%, ** sig@10\%

Table 4.6 show the regression results examining the impact of Asset composition on $E R N Y$. The $R^{2}$ is $65.55 \%$ with and adjusted value of $54 \%$. The $F$-stat of 16.231 (p-value $=0.00)$ and is significant at $5 \%$. The white adjusted standard errors were employed to control for potential heteroskedasticity in the estimation and hence the estimation results are free from heteroskedasticity. The Durbin Watson $(D . W)$ value of 2.01 suggests that the presence of serial correlation between the errors is unlikely in the model. The analysis of coefficients reveals that $C A$ has a positive $(0.005)$ effect on $E R N Y$ and statistically significant at $5 \%(p=0.00), P P E$ has a negative effect $(-0.0424)$ though not significant at $5 \%(p=0.7149)$. The effect of $L T I$ is positive $(0.379)$ though not statistically significant $(p=0.4518)$ at $5 \%$. The effect of $I N T$ is negative $(-3.573)$ and statistically significant $(\mathrm{p}=0.000)$ at $5 \%$. The effect of $L I Q$ is positive $(0.0108)$ though not statistically significant $(p=0.5251)$ at $5 \%$. LEV, INF and GDP are all not significant at $5 \%$ with beta values of $-0.0121,-0.0099$ and -0.0116 respectively.

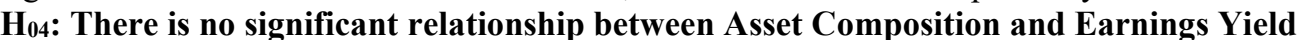

Ho4a: There is no significant relationship between current Assets and ERNY

The coefficient is positive 0.0049 denoting a positive relationship between current asset and ERNY. The p-value is $0.895>0.05$ implying insignificant relationship of current asset to ERNY. Based on p-values we accept the null hypothesis that there is no significant relationship between current asset and ERNY

$\mathrm{H}_{04} \mathrm{~b}$ : There is no significant relationship between Plant Property and Equipment and ERNY

The co-efficient is negative - 0.0424 showing a negative relationship of $P P E$ with $E R N Y$. P-value is $0.7149>0.05$ denoting insignificant relationship. Based on findings we accept the null hypothesis that there is no significant relationship between $P P E$ and $E R N Y$

$\mathrm{H}_{\mathrm{O} 4} \mathrm{c}$ : There is no significant relationship between Long Term Investment and ERNY 
The coefficient is positive 0.3792 denoting a positive relationship between long term Investment and ERNY. The p-value is $0.4518>0.05$ implying no significant relationship of $L T I$ to $E R N Y$. Based on p-values we accept the null hypothesis that there is no significant relationship between $L T I$ and $E R N Y$.

$\mathrm{H}_{\mathrm{O} 4} \mathrm{~d}$ : There is no significant relationship between Intangible Asset and ERNY

The coefficient is negative -3.573 denoting a negative relationship between intangible asset and ERNY. The pvalue is $0.000<0.05$ implying significant relationship of Intangible asset to $E R N Y$. Based on p-values we reject the null hypothesis that there is no significant relationship between current asset and ERNY and confirm significant relationship amongst the variable.

\section{Discussion}

In model four and table 4.6 we examine the relationship between asset composition and earnings yield. The relationship of assert composition and earnings yield showed that, Current assets and LTI have statistical positive significant relationship with earnings yield implying that relation an increase in the variables increases earnings yield. Conversely, $P P E$ and Intangible showed negative significant statistical relation implying that an increase in the variables reduces earnings yield. While liquidity is positively statistically insignificant in relating with Earnings yield implying liquidity does not influence earnings yield. However, Leverage, GDP and inflation are statistically significant and positively relates with Earnings yield. When these findings are considered together with the role earnings yield play it becomes more useful the earnings yield (which is the inverse of the PER) indicate the percentage of each naira invested in shares. Earnings yield is deployed by many investment managers to gauge optimal asset allocations. Earnings yield provides an urgent solution to investors interested in investing in firms with stable dividend as it provides an estimate about the returns such investments may provide. Thus, earnings yield is a returns metric providing estimates of how much an investment can earn back for investors, rather than a valuation metric about how much the investment is valued in the market by investors. An overvalued investment can lower earnings yield and, conversely, an undervalued investment can raise earnings yield. The significant positive relation of Current asset and LTI with $\mathrm{f}$ earnings yields therefore imply the variables are relevant in earnings and can clearly indicate how much of investment in shares of the firm has been recovered through earnings thereby giving direction to investors how rapid investments in shareholding could be recovered.

\section{Result of the Relationship of Asset Components and Market Capitalization} Model 5

$M C A P=\beta_{0}+\beta_{1} P P E+\beta_{2} C A+\beta_{3} I N T+\beta_{4} L T I+\beta_{5} G D P+\beta_{6} I N F+\beta_{7} L I Q+\beta_{8} L E V+U_{5}, t$

Table 4.7. Asset Composition and $M C A P$ Fixed Effects Regression

\begin{tabular}{|c|c|c|c|c|}
\hline Variables & Coefficient & Std. Error & t-Statistic & Prob. \\
\hline$C$ & 23.019 & 0.083 & 275.8249 & $0.000 *$ \\
\hline$C A$ & 0.0407 & 0.004 & 9.9976 & $0.000 *$ \\
\hline$P P E$ & -0.2339 & 0.0349 & -6.6986 & $0.000 *$ \\
\hline$L T I$ & -0.16221 & 0.0674 & -2.4073 & $0.017 *$ \\
\hline$I N T$ & 1.40512 & 0.283 & 4.9702 & $0.000 *$ \\
\hline$L I Q$ & 0.0017 & 0.0011 & 1.6283 & 0.1051 \\
\hline$L E V$ & 0.0069 & 0.004 & 1.9757 & $0.0496^{*}$ \\
\hline INFLA & 0.0297 & 0.006 & 4.9316 & $0.000 *$ \\
\hline$G D P$ & 0.0295 & 0.0086 & 3.4187 & $0.0008 *$ \\
\hline
\end{tabular}

Source: Eviews 10.*sig@ $9 \%$,**sig@10\%

Table 4.7 show the regression results examining the impact of asset composition on $M C A P$. The $R^{2}$ is $98.2 \%$ with and adjusted value of $97.65 \%$. The $\underline{F}$-stat of 180.628 (p-value $=0.00$ ) and is significant at $5 \%$. The white adjusted standard errors were employed to control for potential heteroskedasticity in the estimation and hence the estimation results are free from heteroskedasticity. The Durbin Watson $(D . W)$ value of 1.8 suggest that the presence of serial correlation between the errors is unlikely in the model. The analysis of coefficients reveals that $C A$ has a positive (0.0407) effect on $M C A P$ and statistically significant at $5 \%(p=0.000), P P E$ has a negative effect $(-0.2339)$ and significant at $5 \%(p=0.000)$. The effect of $L T I$ is negative $(-0.162)$ and statistically significant $(p=0.017)$ at $5 \%$. The effect of $I N T$ is positive (1.405) and statistically significant $(p=0.000)$ at $5 \%$. The effect of $L I Q$ is positive $(0.0017)$ though not statistically significant $(p=0.1051)$ at $5 \% . L E V, I N F L A$ and GDP are all statistically significant at $5 \%$ with beta values of $0.0017,0.006973$ and 0.02952 respectively.

$H_{05}$ : There is no significant relationship between Asset Composition and Market Valuation

$\mathrm{H}_{O 5} \mathrm{a}$ : There is no significant relationship between current Assets and $M C A P$.

The coefficient is positive 0.0407 denoting a positive relationship between current asset and $M C A P$. The p-value is $0.000<0.05$ implying significant relationship of current asset to $M C A P$. Based on $\mathrm{p}$-values we reject the null 
hypothesis that there is no significant relationship between current asset and $M C A P$.

$\mathrm{H}_{05} \mathrm{~b}$ : There is no significant relationship between Plant Property and Equipment and $M C A P$.

The co-efficient is negative -0.2339 showing a negative relationship of $P P E$ with $M C A P$. $P$-value is $0.000<0.05$ denoting significant relationship. Based on findings we reject the null hypothesis that there is no significant relationship between $P P E$ and $M C A P$.

$\mathrm{H}_{O 5} \mathrm{c}$ : There is no significant relationship between Long Term Investment and MCAP

The coefficient is negative -0.16221 denoting a negative relationship between long term Investment and $M C A P$. The p-value is $0.017<0.05$ implying no significant relationship of $L T I$ to $M C A P$. Based on p-values we reject the null hypothesis that there is no significant relationship between $L T I$ and $M C A P$.

$\mathrm{H}_{O 5} \mathrm{~d}$ : There is no significant relationship between Intangible Asset and MCAP.

The coefficient is positive 1.40512 denoting a negative relationship between intangible asset and $M C A P$. The pvalue is $0.000<0.05$ implying significant relationship of Intangible asset to $M C A P$. Based on p-values we reject the null hypothesis that there is no significant relationship between current asset and $M C A P$ and confirm significant relationship amongst the variable.

\section{Discussion}

From model five and table 4.7 we examine the relationship between asset composition and MCAP. Current asset and Intangibles have positive significant relationship with Market valuation implying that an increase in current asset and intangibles such as goodwill increases market value. On the other hand, an increase in PPE and LTI reduces $M C A P$ because of the statistical significant relation of the variables to $M C A P$. However, at the macro level, Inflation and $G D P$ significantly relate with Market valuation implying that an increase in inflation and $G D P$ increases $M C A P$. At the micro level firm liquidity does not significantly relate with $M C A P$ while leverage significantly relate with $M C A P$. An increase in leverage increases $M C A P$. (Tax advantage of debt). The significant positive relation of Current assets and Intangibles imply that investors price the firm higher with higher investments in $C A$ and Intangibles. Similarly, increased investments in PPE and LTI reduces market valuation.

\section{Result of the Relationship of Asset Components and Tobin's Q Model 6 \\ $T O B Q=w_{0}+w_{1} P P E+w_{2} C A+w_{3} I N T+w_{4} L T I+w_{5} G D P+w_{6} I N F+w_{7} L I Q+w_{8} L E V+U_{6}, t$} Table 4.8. Asset Composition and TOBIN'S $Q$ Fixed Effects Regression

\begin{tabular}{|c|c|c|c|c|}
\hline Variables & Coefficient & Std. Error & t-Statistic & Prob. \\
\hline$C$ & 154932.8 & 6910.799 & 22.418 & $0.0000^{*}$ \\
$C A$ & -1663.243 & 463.3095 & -3.58991 & $0.000^{*}$ \\
$P P E$ & 850.403 & 2357.573 & 0.36071 & 0.719 \\
LTI & 972.483 & 4772.509 & 0.20377 & 0.839 \\
$I N T$ & -2759.194 & 1290.103 & -2.13874 & $0.034^{*}$ \\
LIQ & 1231.026 & 74.84945 & 16.447 & $0.000^{*}$ \\
LEV & -845.768 & 112.1274 & -7.5429 & $0.000^{*}$ \\
INFLA & 790.142 & 413.6367 & 1.9102 & $0.058^{* *}$ \\
GDP & 480.2242 & 487.0556 & 0.9859 & 0.325 \\
\hline R-squared $=$ 0.92. Adjusted $R^{2}=0.897$. F.stat=38.7258. P(f-stat) $=0.000$. D. W= 2.2. Hausman $(p$-value $)=$ \\
0.014
\end{tabular}

Source: Eviews 10.*sig@ @\%,**sig@10\%

Table 4.8 show the regression results examining the impact of Asset composition on TOBINQ. The $R^{2}$ is $52.91 \%$ with and adjusted value of $38.63 \%$. The $F$-stat of $13.71(\mathrm{p}$-value $=0.00)$ and significant at $5 \%$. The white adjusted standard errors were employed to control for potential heteroskedasticity in the estimation and hence the estimation results are free from heteroskedasticity. The Durbin Watson $(D . W)$ value of 2.2 suggest that the presence of serial correlation between the errors is unlikely in the model. The analysis of coefficients reveals that $C A$ has a negative (-1663.243) effect on TOBIN's $Q$ and statistically significant at $5 \%(p=0.004), P P E$ has a positive effect (850.4034) though not significant at $5 \%(p=0.7187)$. The effect of $L T I$ is positive $(972.48)$ though not statistically significant $(p=0.8388)$ at $5 \%$. The effect of INT is negative $(-2759.194)$ and statistically significant $(\mathrm{p}=0.0337)$ at $5 \%$. The effect of $L I Q$ is positive (1231.026) and statistically significant $(p=0.000)$ at $5 \%$. The effect of $L E V$ is negative $(-845.768)$ and statistically significant $(\mathrm{p}=0.000)$ at $5 \% . G D P$ and INFLA both have positive beta values of 0.480 .22 and 790.142 respectively though only INFLA is significant at $10 \%$.

\section{$\mathbf{H}_{06}$ : There is no significant relationship between Asset Composition and TOBIN'S $Q$}

$\mathrm{H}_{\mathrm{O}} \mathrm{a}$ : There is no significant relationship between current Assets and TOBIN'S $Q$

The coefficient is negative -1663.243 denoting negative relationship between current asset and TOBIN'S Q. The p-value is $0.000<0.05$ implying significant relationship of current asset to $T O B I N$ ' $S Q$. Based on p-values we reject the null hypothesis that there is no significant relationship between current asset and TOBIN'S $Q$. 
$\mathrm{H}_{06} \mathrm{~b}$ : There is no significant relationship between Plant Property and Equipment and TOBIN'S Q.

The co-efficient is positive 850.403 showing a positive relationship of $P P E$ with $T O B I N Q$. $\mathrm{P}$-value is $0.719>0.05$ denoting insignificant relationship. Based on findings we accept the null hypothesis that there is no significant relationship between $P P E$ and TOBIN'S $Q$

$\mathrm{H}_{\mathrm{O} 6 \mathrm{c}} \mathrm{c}$ There is no significant relationship between Long Term Investment and TOBIN'S $Q$.

The coefficient is positive 972.483 denoting a positive relationship between long term Investment and TOBIN'S $Q$. The p-value is $0.839>0.05$ implying no significant relationship of $L T I$ to TOBIN'S $Q$. Based on p-values we accept the null hypothesis that there is no significant relationship between $L T I$ and TOBIN'S $Q$.

$\mathrm{H}_{\mathrm{O} 6} \mathrm{~d}$ : There is no significant relationship between Intangible Asset and TOBIN'S $Q$

The coefficient is negative -2759.194 denoting a negative relationship between intangible asset and TOBIN'S $Q$. The p-value is $0.0034<0.05$ implying significant relationship of Intangible asset to TOBIN'S $Q$. Based on p-values we reject the null hypothesis that there is no significant relationship between current asset and TOBIN'S $Q$ and confirm significant relationship amongst the variable.

\section{Discussion}

In model 6 and table 4.8 asset composition and TOBIN's $Q$ is considered. Current Asset and Intangible have positive and significant relationship with TOBIN'S $Q$ implying and increase in the variables increases TOBIN's $Q$. Conversely, $P P E$ and $L T I$ have negative and statistically insignificant relationship with TOBIN's $Q$. This finding agrees with $\mathrm{Li}$ (2004) which showed negative association between investment and future profitability is robust to scaling of investment and conservative accounting effects. Liquidity relates positively and significantly with $T O B I N Q$ while leverage relates negatively and insignificantly. Increase borrowing constrains the ability of the firm to replace existing assets. At the macro level, GDP and inflation positively and insignificantly relate with Tobin. TOBIN's $Q$ estimates the relation between how the market perceives equity and its intrinsic value. It assesses how a firm is valued. A low valuation (between 0 and 1) means that replacement cost of asset is greater than valuation of its shares implying undervaluation of the shares. On the other hand, when valuation is greater than 1 it implies firm's shares is costlier than the cost of replacing the asset connoting overvaluation. This yardstick of measuring shares is the driver of investment decisions using Tobin's $Q$ ratio. It is based on the underlying notion that the market value of a business is equivalent to its replacement cost., when the result of the study is assessed in line with the role of TOBIN's Q, an increase positive relation of TOBIN's $Q$ to current assets and Intangibles connotes market positively price the variables with positive impact on market value of the firm. Contrastingly, with increased investment in $P P E$ and $L T I$, the market value of the firm is insignificantly mitigated implying that the replacement value of the business is constrained. The reason may not be farfetched as increase investments impact negatively on cash flow and the disposable resources available to the firm. Furthermore, increased investment in PPE and LTI increases the ability of the firm to securitize its borrowing. Although the firm may enjoy tax advantage from increased borrowing the risk of bankruptcy is increased thereby mitigating firm valuation by the market. The negative association of leverage to TOBIN's $Q$ clearly is an indication that the market price down highly geared firms because of risk of liquidation. Contrastingly, liquidity significantly positively relate with TOBIN'S $Q$ implying that businesses are valued higher with increased liquidity

\section{Conclusion and Recommendation}

From the result of the study we found that market reacts negatively to increases in $P P E$ and Long-term Investment as there is a negative significant relationship of $P P E$ and $L T I$ on MCAP. We can also conclude that the market reacts positively to Intangibles and current assets with the positive significant relationship of the variables to MCAP. First, intangibles may contribute to the future earnings potential of the entity in terms of patents, intellectual property, good business reputation and good will. Increase investment in $P P E$ increases $R O A$. Result should be interpreted with caution as $P P E$ could be held for timing of asset transaction which may be for income massaging or economic purpose.

Increased investments in $P P E$ and $L T I$ reduces returns on equity. Also, increases in $C A, L T I$ and Intangible increases $R O A$. This may be due to securitization of $P P E$ for debts. It is important to also note that increases in all spectrum of the asset increases return on assets. This may be due to the size advantage which huge assets confer on firms resulting in economy of scale. Increase in debt reduces earnings due to equity holders because of interest payments. Increase investments in $C A$ increases $R O A, R O E, E R N Y$ and market capitalization. Earnings yield indicates how much a firm generates per naira of investment. The positive significant association of $C A$ with earnings yield is an indication that it increases returns to investors and increases $C A$ creates positive market outlook through share pricing. Increase in Intangibles increases PER, ROA, ROE and MCAP and reduces ENRY and TOBIN's $Q$. The reason could be deduced that intangibles create positive outlook for the firm in terms of goodwill, patents, intellectual property and good business reputation and these are factors which investors consider when making investment decisions as it helps them in determining the future potentials of their investment. Leverage, inflation and $G D P$ exert significant positive influence on market valuation while liquidity, inflation and GDP 
affects firm value measured by ability to replace its assets. Conversely, leverage exert significant negative effect on the ability of firm to replace its assets measured by TOBIN's $Q$. This may be due to increased interest payments. In sum different classes of asset exert diverse influence on different spectrum of performance. We recommend that IPO firms should invest less in PPE and Long-Term Assets to avoid negative investors' perception while at the same time increasing investment in Current assets and developing intangibles. Also, firms with high asset base should increase leverage to enjoy tax advantage. We also recommend that firms with low asset base should avoid increased borrowing to mitigate risk of bankruptcy.

Future Research

The study examined asset composition and effects on performance using services firms (banking and insurance) and manufacturing firms. Future studies can comparatively ascertain the effect of asset composition of service and manufacturing firms to determine the extent to which it affects each of the sector. Future studies can also have examined asset structure and firm value using Enterprise value multiples.

Implication to Theory and Practice

The study confirmed that asset composition affects performance and a judicious mix of asset improves performance. Improve performance increases firm value. Thus, partially agreeing with Modigliani and Miller that asset determines firm value. The different relationship which different composition of assets have with different performance metrics require that Managers exercise caution in deploying assets at each stage of the business cycle and during peculiar circumstances such as initial public offer or during financing decisions such as increased borrowing. The positive significant relationship of leverage with $M C A P, R O A, E R N Y, R O E$ denoting increase in leverage increases the variables agreed with trade-off theory which postulates that high leverage confers tax advantage and increases earnings.

\section{References}

Acharya, V., R. Sundaram, and K. John, 2004, .Cross-Country Variations in Capital-Structures: The Role of Bankruptcy Codes,.Working paper, New York University.

Ansari, $m \&$ Gowda,s (2017). Impacts of asset tangibility and capital structure on financial performance of listed oil and gas companies in India EPRA International Journal of Economic and Business Review e-ISSN : 2347 - 9671|p- ISSN : 2349 - 0187 Volume - 5, Issue- 12, December 2017 110-114

Azadi, M. (2013). The relationship between changes in asset structure and operating earnings in the Tehran Stock Exchange (TSE). Trends in Advanced Science and Engineering (TASE), 7(1), 30-34.

Baek, J.S, Kang, J.K and I. Lee, I (2006) "Business Groups and Tunneling: Evidence from Private Securities Offering by Korean Chaebols," Journal of Finance, Vol. 61, No 5, 2006, pp. 2415-2449. http://dx.doi.org/10.1111/j.1540-6261.2006.01062.x

Barnea, A., ROEn, J. and Sadan, S. (1976) 'Classificatory smoothing of income with extraordinary items', The Accounting Review, January, pp.110-122

Bartov E. (1993).The Timing of Asset Sales and Earnings, Manipulation. The Accounting Review, Vol. 68, No. 4

Bartov, E., Goldberg, S and Kim, M.(2004). Comparative Value Relevance among German, U.S. and International Accounting Standards: A German Stock Market Perspective. Working paper, New York University.

Black, E.L., Sellers, K.F. and Manly, T.S.(1998) 'Creative accounting using asset sales: an international study of countries allowing noncurrent asset revaluation', Journal of Business Finance and Accounting, 25(9) \& (10), November/December, pp.1287-1317

Braun, M., 2003. Financial Contractibility and Asset Hardness,.mimeo, Harvard University

Bryman, A. and Bell, E. (2003). Business Research Methods. Oxford: Oxford University Press

Bushman, R., \& Piotroski, J. (2006). Financial reporting incentives for conservative accounting: The influence of legal and political institution. Journal of Accounting and Economics, 42, 107-148. http://dx.doi.org/

Cai, F., \& Wong, H. (2010). The Effects of IFRS adoption on global capital market integration. International Business \& Economic Research Journal,9(10), 25-34. Retrieved on March 11, 2014 from http://www.journals.cluteOnline.com/index.php/IBER/article/view/636/622

Campello, M., \& Giambona, E. (2010). Asset tangibility and capital structure. Retrieved from http://www.ebs.edu/fileadmin/redakteur/funkt.dept.../100323 Giambona.pdf

Claessens, S., and L. Laeven, 2003, Financial Development, Property Rights and Growth,.Journal of Finance 58, 2401-2436.

Combs J.G. Crook, T.R. \& Shook C. L. (2005). The dimension of organizational performance and its implications for strategic management research. In D.J. Ketchen \& D.D. Bergh (eds) research metholofy in strategy and management (pp: 259-286) san Diego Elsevier.

Cameron, K. (1986), effectiveness as paradox. Consensus and conflict in conceptions of organizational effectiveness. Management science 32(5), 539-553.doi 10:1287/mnsc. 32.5.539 
Cameron K. (1986) A study of organizational effectiveness and its predictors. Management science 32(1), 87-112 doi. $10.1287 / \mathrm{mnsc} .32-1.87$

Caneghem, V.T (2002) 'Creative accounting induced by cognitive reference points', British Accounting Review, 34, pp.167-78

Carneiro, J.M. T. Silva J.F. Tocha A. \& Dib L.A.R. (2007) Building a better measure of business performance. RAC -Eletronica /(2) 114-135. Retrieved from http:www.anpad.org.br/periodicos pdf/a6.39pdf.

Chai, H., Tang, Q., Jiang, Y., \& Lin, Z. (2010). The Role of International Financial Reporting Standards in Accounting Quality, Evidence from the European Union. Journal of International Financial Management and Accounting. Retrieved on March 11, 2014 from http://dx.doi.org/10.1111/j.1467-646X.2010.01041.x

Cheung, Y.L, Rau, P.R and Stouraitis, A. (2006). Tunneling, Propping and Expropriation: Evidence from Connected Party Transactions in Hong Kong," Journal of Financial Economics, Vol. 82, No. 2, 2006, pp. 343-386.

Christensen, H.B., E. Lee, and M. Walker. (2007). Incentives or Standards: What Determine Accounting Quality Changes Around IFRS Adoption? Working Paper Manchester Business School.

Christensen H., Lee E. \& Walker M. (2008): incentives of Standards: what determines accounting quality changes around IFRS Adoption? A paper presented at the annual meeting of the American Accounting Association in Anaheim California 3-6 Aug 2008. America Accounting Association. Available at SSRN: http://ssrn.com/abtract $=1013054$

Clarkson, P. Hanna J. Richardson G. \& Thompson R. (2010): The impact of IFRS Adoption SSRN:http://ssrn.com/abstract $=1614362$

Clarkson M. B.E. (1995). A stakeholder framework for analyzing and evaluating corporate social performance. The Academy of management review 20(1), 92-117. 102307258888.

Connolly, T. Conlon E. J. \& Deutsch, S. J. (1980) Organizational effectiveness a multiple constituencies approach. Academy of management review, 5 (2) 211-217.doi 10.2307/2574430

Demir, F. (2005). Determinants of manufacturing firm profitability under uncertainty and macroeconomic volatility: Evidence from an emerging market. Retrieved from http://www.ou.edu/cas/econ/wppdf/Determinants\%20.pdf

Demirbag, M. Tatoglu E, Tekinus, M. \& Zam, S. (2006). An analysis of the relationship between TQM implementation and organizational performance. Evidence fram turikish SMEs journal of manufacturing technology management

Dhillon, A. S., \& Vachhrajani, H. (2012). Impact of operational efficiency on overall profitability-A case study of GIPCL. Retrieved from Http://amrita.edu/asb/pdfs/working paper

DonglinLi Lzryadnova, O. (2013). Investments in fixed assets in February 2013. Retrieved from http://www.iep.ru/files/RePEc/gai/recdev/108Izryadnova.pdf

Dong, Y. L., Charles, K. Y., \& Cai, D. (2012). What drives fixed asset holding and risk-adjusted performance of corporates in China? An empirical analysis. International Real Estate Review, 15(2), 141-164.

DonglinLi Lzryadnova, O. (2013). Investments in fixed assets in February 2013. Retrieved from http://www.iep.ru/files/RePEc/gai/recdev/108Izryadnova.pdf

Dowling, J. and Pfeffer, J.(1975) 'Organisational legitimacy: social values and organisational behavior', Pacific Sociological Review, 18 (1), (1975) pp. 122-136.

Frank, M. Goyal, Z. \& Vidhan, K. (2011). Trade-off and Pecking Order Theories of Debt. Handbook of Empirical Corporate Finance: Empirical Corporate Finance.

Friend, I., and L. Lang, 1988, .An Empirical Test of the Impact of Managerial Self-Interest on Corporate Capital Structure,.Journal of Finance 43, 271-281.

Gilson, S., 1993, Management Turnover and Financial Distress, in E. Altman (ed.) Bankruptcy and Distressed Restructurings, Business One Irwin, Homewood, Ill.

Gilson, S., K. John, and L. Lang, 1990, .Troubled Debt Restructurings: An Empirical Study of Private Reorganizations of Firms in Default,.Journal of Financial Economics 27, 315-353.

Gramlich, J.D., McAnally, M.L. and Thomas, J.: 2001 'Balance sheet management: the case of short-term obligations reclassified as long-term debt', Journal of Accounting Research, Vol. 39, No. 2, pp. 283-95

Granguli, S.K. \& Aggrawal, S. (2009) ownership structure and firm financial performance: an empirical study in the listed mid -cap Indian companies.

Hanran, L. \& Wenshu, W. (2014) Impact of Intangible Assets on Profitability of Hong Kong Listed Information Technology Companies: Macrothink institute: Hong Kong

Hitt, M.A. (1988). The measuring of organizational effectiveness: multiple domains and constituencies management international review .28(2), 28-40.

Iqbal, A., \& Mati, M. (2012). Relationship between non-current assets \& firms profitability. Retrieved from http://mpra.ub.uni-muenchen.de/44132/MPRA

Ishmael, O., \& Kehinde, J. S. (2013). Profitability analysis trend of components of current assets and their 
prospects in Ajaokuta iron industry. eCanadian Journal of Accounting and Finance, 1(2), 28-37. Retrieved from tp://www.ecanadianjournals.com/index.php/journal-list?layout=edit\&id

Jamali, A. H., \& Asadi, A. (2012). Management efficiency and profitability in Indian automobile industry: From theory to practice. Indian Journal of Science and Technology, 5(5), 2779-2781.

John, K. and E. Ofek (1995) "Asset sales and increase in focus” journal of financial economics 37:105-126

Kantudu, A. S. (2008). Effect of profitability and total assets on the funded status of pension assets of quoted firms in Nigeria. Retrieved from Http://ssrn.com/=1104845

Kotšina, S., \& Hazak, A. (2012). Does investment intensity impact company profitability? A cross-country empirical study. Proceedings from the 2nd International Conference on Economics, Trade and Development IPEDR Vol. 36. IACSIT Press, Singapore.

Kplan R.S. \& Norton D.P. (1992) The balanced scorecard: measures that drive performance Harvard Business Review 70(1) 71-79.

Klapper, L. \& Lnc R. (2002) Corporate governance, investor protection and performance in emerging markets Washington D.C United states: World Bank: mimeographed document.

Koralun-Bereznicka, J. (2013).How Does Asset Structure Correlate with Capital Structure? - Cross-Industry and Cross-Size Analysis of the EU ountries.Universal Journal of Accounting and Finance1

Kothari, C. (2005). Research Methodology:Methods \& techniques. New Delhi: New International(p) ltd. Ebook

Li, D. (2004). The implications of capital investments for future profitability and stock returns-an overinvestment perspective. Retrieved from http://bschool.nus.edu/departments/Finance and Accounting/ of Ulster.

Mawih, K. A.(2014).Effects of Assets Structure on the Financial Performance: Evidence From Sultanate of Oman.

Michael Michaux,M and Myat Mon,(2014) . Asset Tangibility, Macroeconomic Risks, and the Diversi cation Discount Marshall School of Business University of Southern California.April 2014

Modigliani, F., Miller, M., (1958). "The Cost of Capital, Corporation Finance and the Theory of Investment,"The American Economic Review, 48 (3),261-296

Modigliani, F. and Miller, M.(1963). "Corporate Income Taxes and the Cost of Capital: A Correction," The American Economic Review,53(6),433-443

Munawir, S. (2007). Financial Statement Analysis (4th ed.). Molds Fourteenth, Yogyakarta: Liberty.

Myers,S.,C. , (1977). "Determinants of corporate borrowing," Journal of Financial Economics, 5(2),147-176

Myers, S. and N.S. Majluf, (1984). "Corporate financing and investment decisions when firms have informationinvestors do not have," Journal of Financial Economics, 13(4),187-221NSE , (2006) "NSE Handbook, An authoritative 5-Year performance results of listed companies," NSE Nairobi.

Myers, S.C. (1984). The capital structure puzzle. Journal of Finance and Economics, 39,575-592.

Mwangi, M., \& Birundu, E. M. (2015). The effect of capital structure on the financial performance of small andmedium enterprises in Thika Sub-County

Okere, E, O. (2009). International Financial Reporting and Accounting Issues: Imperatives of Attainment of Economic Development in Nigeria, ICAN 39 Annual Accountants Conference

Olatunji, T.E. \& Tajudeen A.A. (2014). Investment in Fixed Assets and Firm Profitability: Empirical Evidence from the Nigerian Banking Sector. Asian Journal of Social Sciences and Management Studies. ISSN:23137401 Vol. 1

Okwo, I. M., Okelue, U. D., \& Nweze, A. U. (2012). Investment in fixed assets and firm profitability: Evidence from the Nigerian brewery industry. European Journal of Business and Management, 4(20), 10-17.

Pandey, I. M. (1999). Financial Management Eighth Edition. New Delhi: Vikas Publishing House PVT LTD.

Poitras, wilkiris \&kwan (2002) "The timing of Assets sales. Evidence of firms journal of business finance \& accounting Sept/oct 2002.

Pouraghajan, A., Malekian, E., Emamgholipour, M.,Lotfollahpour, V., \& Bagheri, M. M. (2012). The relationship between capital structure and firm performance evaluation measures: Evidence from the Tehran Stock Exchange. International Journal of Business and Commerce, 1(9), 166-181.

Reyhani, A. G. (2012). The investigation of effect of assets structure on performance of accepted companies of Tehran Stock Exchange (TSE). Journal of Basic and Applied Scientific Research, 2(2), 1086-1090.

Richard, P. J. Devinney, T.M. Yip, G.S. \& Johnson G. (2009) Measuring organizational performance towards methodological best practice journal of management 35 (3) 718-803 doi 10.1177/01492063083830560

Samwels, J.,M., Wilkies, F.,M., Brayshaw,R.,E., (2007). "Financial Management \& Decision Making," International Thomson Publishing Company.

Schmidt M. (2014) Business Case Essentials. 4th Edition: Solution Matrix Limited. Ebook

Sham, Y.G. \& Mclever, R.P. (2011) Corporate government and financial performance in china: panel data evidence on listed non financial companies. Asia pacific business review. 17(3), 301-324. http//dx.org/10.1080/13602380903522325

Shleifer, A., \& Vishny, R. W. (2003). Stock Market and Driven Acquisitions. Journal of Financial Economics, 70, 295-311. http://dx.doi.org/10.1016/S0304-405X(03)00211-3 
Slovin, M. M. Sushka, and S. Ferraro (1995), “A comparison of the information conveyed by Equity carveouts, spin-offs and asset sell-offs” journal of financial economics 37:89-104

Venkatraman N., \& Ramanujam V. (1986). Measurement of business performance in strategy research: a comparison of approaches academy of management review. 1(4), 801-814.dol 102307/258398.

Waddock, S.A. \& Graves, S.B. (1997) Quality of management and quality of stakeholder relations. Business and society, 36(3), 250-279. doi 10:1177/000765039703600303

Wamugo, L.M. Muathe, S.M. \& Kosimbei, G (2014). Relationship between Capital Structure and Performance of Non- Financial Companies Listed in Nairobi Securities Exchange, Kenya. An Online International Research Journal, Vol. 1

Wolk, H. J. Francis and M. Tearney (1989), Accounting Theory: A conceptual and institutional approach $2^{\text {nd }}$ ed., Boston Kent Publishing.

Zammuto, R.F. (1984). A comparison of multiple constituency models of organizational effectiveness. Academy of management review 9(4), 606-616. doi 10:2307/258484.

ZhengSheng, Nuo, X. \& Zhi, X. (1997). The research of the optimal allocation of assets structure and business performance. Res. J. Econ. Bus. ICT, 8: 1-5 